\title{
Teststrategier og testmotivasjon: Fire niendeklassingers erfaringer med nasjonal prøve i lesing
}

\author{
Ragnar Arntzen`, Ulf Rune Andreassen, Jannicke Karlsen og \\ Bjørn Harald Kvifte \\ Høgskolen $i$ Østfold
}

\section{Sammendrag}

Denne studien bygger på intervjuer med fire flerspråklige elever om deres deltakelse på nasjonal prøve i lesing på 9. trinn. Intervjuene fokuserte på temaene testmotivasjon og teststrategier under gjennomføringen av leseprøven. Gjennom samtalene fant vi at elevene var motiverte for å delta på prøven selv om resultatene på denne ikke gav utslag på karakterene. De som skåret høyt så ut til å bruke et bredere register av teststrategier enn de elevene som skåret lavt. Elevenes opplevelser, erfaringer og refleksjoner rundt testmotivasjon og teststrategier komplementerer den kunnskapen vi har om nasjonale leseprøver siden det fins få kvalitative studier om elevers egne perspektiver på testmotivasjon og teststrategier og ingen om den gruppen elever vi studerer.

Nøkkelord: Flerspråklige elever; lesevaner; nasjonale prøver $i$ lesing; testmotivasjon; teststrategier; ungdomstrinnet

\begin{abstract}
Test strategies and test motivation: The experience of participation in national reading test for four 9 th graders

The current study examines the experiences and reflections of four multilingual students' participation in the national reading test in 9th grade using interviews. The interviews focused on test motivation and test strategies when conducting the reading test. We found that the students were motivated to participate, even though the test results did not have consequences for their grades. The high performing students seemed to use a broader register of test strategies than the low performing. The students' experiences and reflections about test motivation and test strategies complement our knowledge of national test-participation since there are few qualitative studies of students' own perspectives on motivation and test (taking) strategies and no studies on the group of students we examine.
\end{abstract}

Keywords: Multilingual students; reading habits; national reading tests; test motivation; test strategies; lower secondary school

Responsible editor: Oddny Judith Solheim

Received: October, 2018; Accepted: June, 2019; Published: November, 2019

^Korrespondanse: Ragnar Arntzen, epost: ragnar.arntzen@hiof.no

(C) 2019 R. Arntzen, U. R. Andreassen, J. Karlsen og B. H. Kvifte. This is an Open Access article distributed under the terms of the Creative Commons Attribution 4.0 International License (https://creativecommons.org/licenses/by-nc/4.0/), allowing third parties to copy and redistribute the material in any medium or format and to remix, transform, and build upon the material for any purpose, even commercially, provided the original work is properly cited and states its license. Citation: R. Arntzen, U. R. Andreassen, Ұ. Karlsen og B. H. Kvifte. "Teststrategier og testmotivasjon: Fire niendeklassingers erfaringer med nasjonal prøve i lesing” Nordic fournal of Literacy Research, Vol. 5(2), 2019, pp. 79-99. 


\section{Innledning}

Leseforståelse er en kompleks ferdighet som påvirkes av en rekke faktorer. Lesevaner (Roe \& Lie, 2009), motivasjon for lesing (Eklöf, 2010; Wigfield \& Eccles, 2000) og lesestrategier (Samuelstuen \& Bråten, 2005) er eksempler på faktorer som ofte blir trukket fram. Norske ungdomsskoleelevers leseforståelse følges både gjennom nasjonale leseprøver og internasjonale kartleggingsprøver som PISA. Når leseforståelse kartlegges ved hjelp av en lesetest, kan imidlertid andre faktorer enn de som spiller inn ved annen lesing ha innvirkning på prestasjonen, spesielt elevenes motivasjon for å gjennomføre testen (Hopfenbeck, 2010) og hvilke teststrategier de bruker (Cohen \& Upton, 2006). I denne artikkelen undersøker vi hvordan fire norskfødte elever med innvandrerforeldre (også kalt andregenerasjons minoritetselever) opplever det å delta på den nasjonale prøven i lesing på 9. trinn, med særlig fokus på testmotivasjon og teststrategier.

På nasjonale og internasjonale leseprøver skårer denne gruppen ofte i snitt på et nivå mellom majoritetselever og førstegenerasjons minoritetselever (Kjærnsli \& Jensen, 2016; Steinkellner, 2017). Det er vanlig at det skjer et språkskifte i andregenerasjonen, og at minoritetselevene får andrespråket som sitt primærspråk, ofte tidlig i skoleløpet (Montrul 2013). Vi kjenner ikke til tidligere studier som undersøker testmotivasjon og teststrategier hos denne gruppen.

Det er en mulighet for at innvandrerbakgrunn kan virke inn på holdninger til skolearbeid og motivasjonen for å gjøre det godt på prøver og tester hos andregenerasjons minoritetselever (jf. utdanningsdriv; Bakken \& Hyggen, 2018). Når det gjelder strategier, så beskriver Kulbrandstad (2003) at elever som leser på et andrespråk, kan gjøre bruk av enklere og mer overflatiske strategier enn elever som leser på sitt førstespråk. Hvorvidt det er tilfelle for andregenerasjons minoritetselever som har hele sin skolegang i Norge og norsk som primærspråk, er usikkert. Det er dessuten reist kritikk mot at andrespråkselever deltar på nasjonale prøver (Tonne \& Pihl 2013; Monsen \& Holm, 2018). Det er derfor flere grunner til at det er aktuelt å se nærmere på hvordan denne elevgruppen selv opplever det å delta på slike prøver.

\section{Nasjonale prøver i lesing}

Nasjonale prøver i lesing for 8. og 9. trinn er blitt arrangert siden 2010, og det er samme prøve for de to trinnene. De nasjonale prøvene skal måle den generelle lesekompetansen hos alle elever og tar utgangspunkt i målene for lesing i læreplanen (Roe, Ryen \& Weyergang, 2018). Lesekompetansen blir inndelt i fem mestringsnivåer, der 1 er laveste og 5 høyeste nivå. Det er leseforståelse som blir testet, med fokus på de tre leseaspektene «å finne informasjon i tekster, å tolke og sammenholde informasjon, å reflektere over og vurdere teksters form og innhold" (Utdanningsdirektoratet 2017a:8). Prøvesettet inneholder sju tekster i ulike sjangre, det er ca. 45 oppgaver, og de skal besvares i løpet av 90 minutter. Tre fjerdedeler av oppgavene er flervalgsoppgaver med fire svaralternativ, mens resten er åpne spørsmål der elevene må skrive svaret (Roe, Ryen \& Weyergang, 2018). 
Fauskevåg (2016) har sammenliknet de nasjonale prøvene i lesing med lesetestene fra PISA og finner at de nasjonale prøvene har et noe snevrere syn på lesing enn PISA-testene og det som uttrykkes om lesing i Rammeverket for grunnleggende ferdigheter. Han kritiserer blant annet de nasjonale prøvene for ensidig å fokusere på de tre leseaspektene (finne, tolke og reflektere) og å gi for liten plass til viktige dimensjoner ved leseprosessen, som motivasjon og strategibruk. I PISA kartlegges motivasjon og strategibruk gjennom et spørreskjema som elevene besvarer, mens selve leseprøven er ganske lik i de to prøvekonseptene.

\section{Testmotivasjon}

Innenfor teori om selvregulert læring er både strategibruk og motivasjon komponenter av betydning for elevers ferdigheter og prestasjoner (Pintrich \& De Groot, 1990; Schiefele, Schaffner, Möller \& Wigfield, 2012; Zimmerman, 2000). Som Eklöf (2010) påpeker, er motivasjon et vidt begrep som kan måles på ulike nivåer. Motivasjon knyttet til en testsituasjon måler motivasjon på et oppgavespesifikt nivå. Dette kalles testmotivasjon (test-taking motivation) og er en egen retning innenfor motivasjonsforskning. Baumert og Demmrich (2001) definerer det som «villigheten til å engasjere seg i arbeid med testoppgaver og å investere anstrengelse og utholdenhet under testen" (vår oversettelse, s. 441).

Testmotivasjon kan knyttes til testing innenfor ulike læringsområder. I vår studie knyttes det til området leseforståelse. Testmotivasjon knyttet til leseoppgaver kan i større grad enn ved lesing utenfor testsituasjoner være drevet av ytre forhold, ved at det er snakk om pålagte oppgaver der elevene vet at de blir vurdert, enten denne vurderingen har konsekvenser for karakterene eller ikke (Eklöf, 2010). Manglende testmotivasjon kan sees på som en trussel mot validiteten av skårene på en lesetest, fordi elevene dermed ikke får vist hva de er gode for (Knekta \& Eklöf, 2015). Motsatt av motivasjon vil testangst ofte ha en negativ effekt på elevers prestasjoner (Birenbaum \& Gutvirtz, 1993; Wolf \& Smith, 1995). Eklöf og Nyroos (2013) fant imidlertid bare svake sammenhenger mellom engstelse og prestasjoner, mens Birenbaum og Gutvirtz (1993) fant tydelig, negativ sammenheng for svake elever. Dette støttes av en studie av Wolf og Smith (1995), som fant at studenter med høy motivasjon og lav testangst presterte best. Hvorvidt testen hadde konsekvenser for karakteren, var også av betydning (se også Zilberberg, Finney, Marsh \& Anderson, 2014).

Når en test ikke har konsekvenser for eleven, kalles den en lowstakestest, i motsetning til en highstakestest, der eleven vet at resultatet vil ha konsekvenser f.eks. i form av karakterer. På lowstakestester vil en kunne forvente lavere testmotivasjon siden resultatene ikke får følger eller er forbundet med personlige fordeler ved å gjøre det godt (Knekta \& Eklöf, 2015). Lav testmotivasjon har for eksempel blitt brukt som mulig forklaring på norske elevers relativt svake resultater i PISA-sammenheng (Hopfenbeck, 2010). Hopfenbeck og Kjærnsli (2016) undersøkte testmotivasjon ved å intervjue 40 elever som deltok på den norske delen av PISA-testene i 


\section{R. Arntzen, U. R. Andreassen, F. Karlsen og B. H. Kvifte}

2006, 2009 og 2012. Studien viste at elevene i overveiende grad var motiverte for å giøre sitt beste, til tross for at resultatene ikke hadde noen innvirkning på elevenes karakterer.

Det er utviklet flere teorier som er ment å konseptualisere testmotivasjon og å forstå elevers innsats i en testsituasjon. Ifølge Penk og Schipolowski (2015) er forventning-verditeorien (the expectancy-value theory) til Wigfield og Eccles (2000) en av de mest brukte. Teorien vektlegger to aspekter ved motivasjonen: forventningen eleven har om å kunne mestre oppgaven, og hvilken verdi eleven tillegger oppgaven. Det første aspektet handler om elevens svar på spørsmålet «Er jeg i stand til å gjøre denne oppgaven?». Slike mestringsforventninger er ofte bygd på tidligere erfaringer med å mestre eller mislykkes med liknende oppgaver eller situasjoner. Ros og anerkjennelse fra andre vil også kunne påvirke forventningene en har til seg selv (Wigfield \& Eccles, 2000).

Det andre aspektet, verdiaspektet, handler om spørsmålet «Hvorfor skal jeg giøre denne oppgaven?». Wigfield og Eccles (2000) nevner fire forhold som kan påvirke en oppgaves verdi: viktighet, interesse (indre motivasjon), nytte og omkostninger. Viktighet beskriver hvilken verdi eleven tillegger det å gjøre det bra på oppgaven og henger sammen med i hvilken grad eleven har sin identitet knyttet til gode skoleprestasjoner. Interesse beskriver i hvilken grad eleven har glede (enjoyment) av å giøre oppgaven, mens nytte beskriver hvilket framtidig utbytte man kan få av å gjøre oppgaven. Omkostninger dreier seg om negative følger av å engasjere seg i oppgaven, f.eks. i hvilken grad det å legge ned innsats i oppgaven gjør at man ikke får vært med på andre aktiviteter. Emosjonelle omkostninger ved å utføre oppgaven kan f.eks. dreie seg om at eleven risikerer å møte egen tilkortkommenhet ved å ikke få til oppgaven. Ifølge Wigfield og Eccles (2000) har de fleste empiriske studier som har brukt denne modellen, fokusert på de tre første komponentene. Høy mestringsforventning til og verdsetting av det å gjennomføre tester fører gjerne til at testtakeren anstrenger seg mer (Penk \& Schipolowski, 2015). Videre er det vanlig å betrakte interesseverdien som en form for indre motivasjon, mens de andre motivasjonsverdiene regnes som ytre motivasjon (Wigfield \& Eccles, 2000).

Flere korrelasjonsstudier har vist at det er statistisk sammenheng mellom testmotivasjon og prestasjoner på tester (Cole \& Osterlind, 2008; Wise \& DeMars, 2005). Knekta og Eklöf (2015) fant at forventningsaspektet og verdiaspektene viktighet og interesse var signifikant korrelert med prestasjonen på en nasjonal naturfagtest. Også Schiefele og Krapp (1996) framhever betydningen av verdiaspektet: De fant at interesse for et emne hadde signifikant sammenheng med hva studenter husket fra en tekst. Vi kan imidlertid ikke utelukke at det er snakk om spuriøse sammenhenger, fordi det ikke er kontrollert for elevenes ferdighetseller evnenivå som en mulig tredjefaktor. I sin gjennomgang av tidligere forskning fant Penk og Schipolowski (2015) varierende betydning av mestringsforventing i lowstakestester. I sin egen studie brukte Penk og Schipolowski (2015) forventingverdimodellen da de undersøkte forholdet mellom ulike aspekter ved testmotivasjon 
(forventning, verdi og anstrengelse) og prestasjoner i lowstakestester hos 420009. klassinger i matematikk og naturfag. Da fant de bl.a. at mestringsforventing og anstrengelse hadde sterk direkte effekt på prestasjonene, mens verdikomponentene hadde en indirekte effekt ved at de predikerte anstrengelse, som igjen påvirket prestasjonene.

\section{Lese- og teststrategier}

Ifølge Bråten (2007) er det godt dokumentert at gode lesere er mer effektive enn svake lesere i sin bruk av strategier, og at dårlig leseforståelse er kjennetegnet ved at man ikke tar i bruk strategier under lesningen. Strategisk lesing kan defineres som "deliberate, goal-directed attempts to control and modify the reader's efforts to decode texts, understand words and construct meanings of text" (Afflerbach, Pearson \& Paris, 2008, s. 368). Slik bevisst og målrettet innsats rettet mot meningsskaping er noe man gjerne bevisst må ta i bruk når den umiddelbare forståelsen ikke strekker til.

En enkel og mye brukt måte å inndele strategier på er skillet mellom overflatestrategier og dybdestrategier (Alexander, Sperl, Buehl, Fives \& Chiu, 2004; Alexander, 2005; Skaftun \& Solheim, 2014). Overflatestrategier hjelper leseren til å finne mening i en ukjent tekst ved å endre lesetempo og hoppe over ord (Alexander, 2005), samt å orientere seg i teksten før lesingen, stoppe underveis og lese om igjen og prøve å forstå selv om det er enkeltord leseren ikke forstår (Skaftun \& Solheim, 2014). Dybdestrategier går ut på at leseren forholder seg mer selvstendig til teksten som helhet og setter den i sammenheng med egne erfaringer og forforståelse. Slike strategier kan også innebære at man sammenlikner på tvers av tekster, konstruerer alternative forklaringer og stiller spørsmål ved kilden (Alexander, 2005), samt tenker igjennom det en har lest i lys av forkunnskaper, vurderer egen lesing og lager sammendrag (Skaftun \& Solheim, 2014). En kompetent leser vil variere bruken av overflate- og dybdestrategier (Parkinson \& Dinsmore, 2018).

Det å lese i en testsituasjon vil ofte skille seg fra lesing utenfor en testsituasjon, både fordi formålet er annerledes og på grunn av tilstedeværelsen av tidspress. Derfor kan andre strategier enn de som er nevnt over, bli hensiktsmessige. Ofte vil fokus i tekstarbeidet da i større grad være rettet mot å finne svar på spørsmål enn det å forstå teksten (Cohen \& Upton, 2006). Cohen og Upton definerer teststrategier som «those test-taking processes that the respondents have selected and are conscious of, at least to some degree» (2006, s. 5). Et teststrategisk valg leseren blir stilt overfor, er om oppgavene eller teksten skal leses først (jf. Lewandowski, Berger, Lovett \& Gordon, 2016). Å lese oppgavene først vil kunne målrette lesingen, og bruk av en overflatestrategi som å skumlese kan i slike tilfeller være hensiktsmessig fordi det sparer tid. Både det å skanne teksten for å få oversikt og det å gå dypere inn i teksten kan være gode strategier avhengig av hva slags informasjon oppgaven etterspør. Graden av suksess som en teststrategi har for den enkelte elev, vil være relatert til en rekke faktorer som for eksempel oppgavetype, hvilke strategier eleven 


\section{R. Arntzen, U. R. Andreassen, F. Karlsen og B. H. Kvifte}

har til rådighet og hvordan disse blir brukt (jf. Cohen \& Upton, 2006). Det kan derfor være vanskelig å skille mellom lesestrategier og teststrategier i en testsituasjon, siden situasjonen og de oppgavene eleven blir stilt overfor, gir så sterke føringer for hva som er hensiktsmessig. Man kan altså ikke se bort fra at valg av (lese-)strategi i en testsituasjon vil være mer begrunnet ut fra teststrategiske vurderinger enn ønsket om å forstå teksten. Flere av våre informanter fortalte for eksempel at de hadde måttet endre strategi underveis, på grunn av prøvekonseptet (at de skulle velge mellom svaralternativ), tidspress ol. I omtalen av egen undersøkelse har vi derfor funnet det mest hensiktsmessig å bruke teststrategi som fellesbetegnelse for elevenes strategibruk under prøven.

På hvilken måte tidspress påvirker testresultatene, er usikkert. I en studie av voksne fant Walczyk, Kelly, Meche og Braud (1999) at de studentene som leste under et mildt testpress, presterte bedre enn de som leste uten tidspress, eller med et sterkt tidspress. De Paola og Gioia (2016) fant imidlertid at for mange studenter hadde tidspress en negativ effekt på testprestasjonene, og at de studentene som ble mest påvirket, også hadde en forventning om å prestere lavere under tidspress.

Vi vet lite om norske elevers strategier i testsituasjoner. I en studie av de norske resultatene i PISA 2009 fant Roe og Jensen (2017) at de svakeste elevene klarte seg greit når oppgavene spurte etter informasjon som var eksplisitt uttrykt $i$ teksten, og det ikke var for mye konkurrerende informasjon. I denne type oppgaver vil elevene kunne finne svar ved hjelp av overflatestrategier. Størst problemer hadde de svakeste elevene med komplekse fagtekster som krevde at leseren både måtte tolke og reflektere over tekstens helhet, for deretter å måtte kombinere ulike tekstsekvenser (Roe \& Jensen, 2017). I denne type oppgaver trengs dybdestrategier. Dette er delvis i tråd med resultatene til Amundsen og Garmannslund (2015), som fant at ungdomsskoleelever som betraktet seg som gode lesere, i høyere grad hadde kjennskap til lesestrategier enn andre elever. I en studie av elever på 5. trinn fant imidlertid Solheim og Gourvennec (2017) at et flertall av de svakeste leserne opplevde at de hadde gode leseferdigheter.

PISA-studiene har vurdert lesestrategier indirekte gjennom elevers svar på spørsmål om lesestrategier, mens Solheim og Uppstad (2011) kartla elevers teststrategier mer direkte under gjennomførelsen av en lesetest. De undersøkte 18 sjuendeklassingers testatferd der de registrerte hvordan testdeltakerne beveget øynene under en test, både gjennom den første forberedelseslesningen og når elevene svarte på oppgaven og hadde tilgang til teksten. De elevene som lyktes med oppgaven, brukte enten god tid på forberedelseslesningen og tilpasset lesetempoet til tekstens vanskelighetsgrad, eller de skumleste først raskt, og studerte så de relevante tekstpassasjene mens de svarte på oppgaven. De ikke-strategiske leserne virket å være mindre fleksible med å tilpasse lesetempo, og de gav enten raskt opp dersom de ikke fant svar ved å se på illustrasjonene til teksten, eller de fortsatte med å giøre det samme selv om det ikke førte fram. Elevene fikk imidlertid lese teksten før de fikk oppgaven og hadde ubegrenset med tid til å gjennomføre testen, noe som giør at resultatene ikke direkte 
kan generaliseres til mer typiske, tidsavgrensede leseprøver der elever får oppgaver og tekster samtidig.

\section{Lesevaner}

Både PIRLS- og PISA-studier viser at det er samvariasjon mellom elevers lesning på fritida og deres skår på leseprøver (Hvistendahl \& Roe, 2009). I PISA 2009 viste det seg at det var «de elevene som svarte at de aldri leste i fritiden, som skilte seg ut ved å skåre mye lavere på leseprøven enn de som leste» (Roe \& Jensen, 2017, s. 3). Det framkom også at når elever på laveste mestringsnivå leste på fritida, leste de primært tegneserier, ukeblader, aviser og nettbasert lesestoff. Elevene på laveste mestringsnivå skilte seg fra de andre gruppene ved at de svært sjelden leste faktabøker og skjønnlitteratur (Roe \& Jensen, 2017). Også holdninger til lesing ser ut til å henge sammen med leseforståelse, og Hvistendahl og Roe (2009) fant at positive holdninger til lesing og lesehyppighet korrelerte positivt med skårene fra PISA-kartleggingen hos minoritetselever.

\section{Den foreliggende studien}

Flere utdanningsforskere etterlyser studier av elevers testmotivasjon og elevers opplevelser av å delta på leseundersøkelser (Eklöf, 2010; Hopfenbeck \& Kjærnsli, 2016). Elevers testmotivasjon er overraskende lite studert, hevder Eklöf (2010, s. 259), med tanke på at den kan ha sammenheng med prestasjonen. Internasjonale studier om testmotivasjon er i overveiende grad kvantitative (Cole \& Osterlind, 2008; Hopfenbeck \& Kjærnsli, 2016; Hopfenbeck, 2010; Knekta \& Eklöf, 2015; Penk \& Schipolowski, 2015; Schiefele et al., 2012; Schiefele \& Krapp, 1996; Wise \& DeMars, 2005), mens få går i dybden på enkeltelevers opplevelser. Vi har ikke funnet noen norske studier om teststrategier hos elever med flerspråklig bakgrunn, og kan heller ikke se at begrepet er brukt i norsk faglitteratur om lesing. Med utgangspunkt i intervjudata fra fire niendeklassinger på ulike mestringsnivå på den nasjonale prøven i lesing belyser vi følgende spørsmål:

1. Hva kjennetegner testmotivasjon for nasjonal prøve i lesing hos fire andregenerasjons minoritetselever på ungdomstrinnet?

2. Hva kjennetegner disse elevenes teststrategier på leseprøven?

3. I hvilken grad ser vi sammenheng mellom elevenes testmotivasjon og teststrategier på den ene siden og elevenes mestringsnivåer på den andre siden?

\section{Metode}

Utvalg

Informantene er barn av innvandrerforeldre som kom til Norge ca. 3-5 år før barna ble født og inngår i en longitudinell studie av 15 flerspråklige barns språk- og 
leseutvikling, der vi har fulgt barna fra tidlig fase i andrespråksutvikling i førskolealder, til de etterhvert har fått andrespråket norsk som sitt primærspråk (Arntzen \& Karlsen, 2019). Informantene hadde hatt minst to år i barnehage før de begynte på skolen, og hadde dermed hatt opplæring i norsk og vært del av det norske utdanningssystemet i mer enn 10 år da vi intervjuet dem.

Kort tid etter at disse 15 hadde gjennomført nasjonal prøve i lesing på 9. trinn, intervjuet vi dem for å undersøke deres erfaringer med deltakelse på prøven. Vi valgte intervju som metode fordi vi ønsket å gå i dybden på enkeltelevers opplevelser og tanker. I den foreliggende studien undersøker vi testmotivasjon, teststrategi og prestasjon hos et mindre utvalg og har derfor valgt fire informanter ut $\mathrm{i}$ fra følgende kriterier i prioritert rekkefølge. Informantene skulle:

- fordele seg på de to laveste og de to høyeste mestringsnivåer på nasjonal prøve i lesing på 9. trinn (jf. forskningsspørsmål 3)

- ha mest å fortelle om testmotivasjon og teststrategibruk under prøven (jf. forskningsspørsmål $1 \mathrm{og}$ 2)

- ha blitt intervjuet kortest tid etter prøven. Dette kriterium begrunnes med at tanker om opplevelser elever har hatt, helst bør hentes inn kortest tid etter at begivenheten har funnet sted

På bakgrunn av disse kriteriene valgte vi Sara og Kevin, som hadde skåret på de to høyeste mestringsnivåene, og Adrian og Noah, som hadde skåret på de to laveste nivåene på leseprøven for 9. trinn (se Tabell 1). For disse fire var det også bare 1-3 dager mellom prøvedeltakelse og intervju.

\section{Framgangsmåte}

For å finne svar på forskningsspørsmålene utarbeidet vi en intervjuguide og gjennomførte semistrukturerte intervjuer. Informantene hadde tidligere deltatt i fem intervjuer mellom 1. og 8. trinn. I intervjuene prioriterte vi å få god kontakt med informantene, og at de skulle oppleve seg selv som ressurspersoner. Vi startet intervjuene med å presentere prosjektet (bakgrunn, mål, motivasjon, anonymitet), for så å samtale om elevenes videre skole- og utdanningsplaner og lesevaner på fritida. Hoveddelen av intervjuet dreide seg om deltakelsen på den nasjonale prøven $\mathrm{i}$ lesing. Først inviterte vi dem til å fortelle litt generelt om prøven: forberedelser i klassen, den enkeltes opplevelse av prøven og hva som skjedde underveis. Deretter gikk vi mer detaljert inn på selve prøven: Hva husket informantene av de tekstene de hadde blitt prøvd i, hvordan hadde de gått fram for å svare på oppgavene, hva syntes de om de ulike tekstene, hvilke generelle og spesielle utfordringer opplevde de når det gialdt forståelse og eventuelle forkunnskaper de hadde til tekstene. Avslutningsvis bad vi elevene om å vurdere egeninnsats og motivasjon for å delta på nasjonale prøver.

Temaet flerspråklighet tok vi initiativ til å snakke om i den innledende delen av samtalen der vi snakket om lesevaner og leseinteresser, bl.a. hvilke språk elevene 
kunne lese på og hva de eventuelt leste på de ulike språkene. I hoveddelen av intervjuet der vi snakket om erfaringer med den nasjonale prøven i lesing, overlot vi til informantene om og i hvilken grad de ønsket å relatere temaene til sin flerspråklige bakgrunn. Begrunnelsen for dette valget var at enkelte minoritetsspråklige kan oppleve det som stigmatiserende å bli regnet som minoritetsspråklig, andrespråkselev eller innvandrer. Samtale om lesing på ulike språk er derimot en mer ressursorientert tilnærming, og noe som vi har erfaring med at flerspråklige barn og unge liker å snakke om.

Intervjuene varte fra 20 til 40 minutter og ble gjennomført av forfatterne og en forskningsassistent. Det ble gjort lydopptak av intervjuene, som så ble ortografisk transkribert. Vi hadde ikke fått tilgang til prøvesettet før vi møtte elevene og kunne derfor ikke forberede spørsmål knyttet til spesifikke tekster eller oppgaver.

\section{Analyse}

Testmotivasjonen ble analysert ved hjelp av kategoriene fra forventing-verdimodellen (se s.4) (Wigfield \& Eccles, 2000), og vi har derfor kodet informantenes utsagn om motivasjon ut i fra informantenes forventninger om å mestre prøven og hvilken verdi de tilla den. I forventningskategorien plasserte vi utsagn som dreide seg om informantenes forventninger om å gjøre det godt på prøven. Når det gjaldt viktighet, så vi etter utsagn om hvor viktig det hadde vært for informantene å gjøre det godt på prøven. I hvilken grad informantene hadde latt seg engasjere $i$ arbeidet med testen og tekstene, og hvor mye informantene husket av innholdet i de tekstene de arbeidet med, tolket vi som indikator på interesse (jf. Schiefele \& Krapp, 1996). Nytteverdien har å gjøre med hvilken nytte informantene mener innsatsen på prøven vil kunne gi i framtida, og siden det ikke gis karakter, var vi i særlig grad opptatt av om informantene tilla prøven en personlig nytte. Når det gjaldt omkostninger, så vi bl.a. etter utsagn om informantene hadde unnlatt å svare på vanskelige spørsmål, da det kan være en indikasjon på at elevens selvbilde er under press (Wigfield \& Eccles, 1992).

For å analysere informantenes beskrivelser av hvordan de brukte teststrategier, har vi latt oss inspirere av Lewandowski og kollegaer (2016). De beskriver strategier som er bygd opp etter to kjerneelementer: rekkefølge (leses tekst eller oppgave først) og type lesing (skumlesing eller lesing). Rekkefølgen er knyttet til om teksten (skum-)leses før eller etter at oppgavene leses, mens lesing og skumlesing viser til hvor grundig teksten leses. Når det gjaldt skumlesing, delte vi det $\mathrm{i}$ skimming og skanning. Skimming gir leseren et overblikk over innholdet i teksten, mens skanning brukes til å finne spesifikk informasjon. Lesing er mer omfattende (jf. Alexander, 2005; Skaftun \& Solheim, 2014), og brukes for å forstå og huske innholdet i teksten. Inndelingen benyttet vi for å kategorisere hvilken strategi informantene brukte først, altså deres primærstrategi. Videre registrerte vi i hvilken grad informantene tok i bruk andre strategier dersom primærstrategien viste seg å ikke være effektiv, og hva slags strategier de i tilfelle brukte. Disse strategiene kaller vi sekundærstrategier. 


\section{Resultater}

\section{Bakgrunnsinformasjon}

I Tabell 1 presenterer vi resultater fra nasjonale prøver i lesing på 9. trinn og bakgrunnsinformasjon som informantene gav under samtalene, og som vi mener er relevant for å belyse studiens resultater.

Tabell 1. Bakgrunnsinformasjon.

\begin{tabular}{|l|l|c|l|l|l|l|l|}
\hline & S1 & $\begin{array}{l}\text { NLP } \\
\text { tr. 9 }\end{array}$ & Utdanningsplaner & $\begin{array}{l}\text { Holdning } \\
\text { til lesing }\end{array}$ & Lesevaner & $\begin{array}{l}\text { Forb. til } \\
\text { prøven }\end{array}$ & $\begin{array}{l}\text { Kan lese } \\
\text { på S1 }\end{array}$ \\
\hline Noah & Iransk & 1 & $\begin{array}{l}\text { Kunstner eller } \\
\text { fotograf }\end{array}$ & Reservert & Nyheter og sport & Lite & Nei \\
\hline Adrian & Kusjittisk & 2 & Siviløkonom & Reservert & $\begin{array}{l}\text { Nyheter, sport, krim, } \\
\text { fantasi }\end{array}$ & Lite & Litt \\
\hline Kevin & Balkan & 4 & Har ikke bestemt seg & Reservert & Spill på nett og bøker & Lite & Litt \\
\hline Sara & Kusjittisk & 5 & Lege eller ingeniør & Positiv & $\begin{array}{l}\text { Nyheter, bøker: } \\
\text { noveller, krim, eventyr, } \\
\text { japanske tegneserier }\end{array}$ & Lite & Ja \\
\hline
\end{tabular}

S1 = Informantenes førstespråk. For å anonymisere informantene angir vi ikke førstespråkene deres, men språkfamilie eller område der språket har offisiell status.

NLP = Nasjonale leseprøver. Resultatene gis på en skala fra 1-5.

Forb. til prøven $=$ forberedelse til prøven.

Alle informantene hadde gjort seg tanker om videre utdanning. Sara fortalte at hun ville bli lege eller ingeniør, og at foreldrene støttet henne i utdanningsplanene. Kevins foreldre ville gierne at han skulle bestemme seg for et yrke, men han syntes det var vanskelig å velge. Adrian sa at han ville bli sivil- eller samfunnsøkonom, men dette hadde han ikke diskutert med foreldrene. Noah ønsket ikke å ta en lang utdanning, og kunne tenke seg å bli fotograf eller kunstner, imidlertid var mor noe skeptisk til inntektsmulighetene innenfor disse yrkene.

Holdningen til lesing varierte mellom informantene. Sara var den eneste som uforbeholdent uttrykte at hun likte godt å lese. Hun var en aktiv leser innen ulike sjangre og leste mest på norsk, men også noe på førstespråket og på engelsk. De andre tre informantene gav spontant uttrykk for at de ikke var spesielt glad i å lese: «Å lese bøker synes jeg ikke er så veldig gøy» (Kevin), «Er flink til å lese, men liker det ikke» (Adrian), "Ikke bok eller noe da» (Noah). I løpet av samtalene med dem nyanseres allikevel dette bildet. Noah leste både nyheter og sport, og av og til var han på biblioteket og leste faktabøker. Adrian fortalte at han egentlig kunne lese om hva som helst bare det var spennende. Kevin syntes at han leste for langsomt på norsk og hadde derfor begynt å jobbe aktivt med å forbedre lesningen sin ved å låne bøker på biblio-teket: «Hver dag prøver jeg å lese ti sider minst». Dette mente han også ville styrke norskferdighetene: «Og så har [jeg] begynt å lese bøker og sånn på norsk (...) 
sånn at jeg kan lære meg norsk bedre». Både Noah, Adrian og Kevin leste mest på norsk, litt på engelsk, men ingenting på førstespråket.

Informantene kunne ikke huske at de hadde gjort bestemte forberedelser på skolen i forkant av den nasjonale leseprøven. Adrian og Kevin fortalte at de ikke hadde øvd på liknende oppgaver eller på annen måte forberedt seg til prøven, bortsett fra råd fra læreren om å bruke tida og gjøre sitt beste (Kevin). Noah fortalte at de hadde fått råd fra læreren om «å bruke tiden og tenke seg om», mens Sara fortalte at de fikk råd om en nettside der de kunne øve.

Informantene syntes stort sett det hadde vært greit å delta på prøven; bare Kevin følte seg litt ukomfortabel under prøven fordi han var usikker på om han ville klare å besvare spørsmålene innen tidsfristen. Alle uttrykte imidlertid tilfredshet med utfallet av prøven; både Sara og Noah mente prøven gikk bra, Kevin uttrykte at han gjorde det "ganske $\mathrm{OK}$ » og ikke så dårlig som han hadde trodd på forhånd. Aller mest positiv til forventet resultat var Adrian på mestringsnivå 2: «På en skala fra en til ti så hadde [jeg] en sterk åtte på vei til nier, veldig lett, jeg gjorde det veldig bra, synes jeg».

\section{Motivasjon \\ Mestringsforventning}

Det var bare de to informantene på de høyeste mestringsnivåene, Kevin og Sara, som nevnte at de hadde tenkt på prøven på forhånd. Sara fortalte hun fryktet at årets prøve skulle være vanskeligere enn fjorårets, og uttrykte lettelse over at hun kunne besvare spørsmålene ved hjelp av informasjonen i tekstene. Kevin mente at han var en langsom leser og fryktet derfor at han ikke ville få tid til å svare på alle oppgavene, og stilte altså spørsmål ved om han kom til å mestre prøven. Også Sara var opptatt av tidsfaktoren. Hun orienterte seg derfor nøye i materialet for å se «hvor lang tid jeg hadde», holdt øye med tida underveis i prøven og ble lettet da hun oppdaget at hun bare hadde to tekster igjen: «Da så jeg faktisk at jeg hadde god tid».

Noah og Adrian så ikke på tidsfaktoren som noe problem. Noah siterte læreren som hadde gitt ham følgende råd: «Ikke hast, det er ingen konkurranse. Du trenger tid til å tenke». Adrian tok ikke selv opp tidsfaktoren, men på direkte spørsmål fra intervjuer, svarte han at han ikke hadde hatt dårlig tid. Dette kan henge sammen med at han ikke syntes prøven var vanskelig. Han syntes ikke det var noen vanskelige tekster, og når vi spurte om han forstod alle ordene, svarte han: «Ja, ja, jeg kan norsk, jeg».

\section{Oppgavenes verdi}

Det kan se ut til at det å gjøre det godt på prøven var viktig for informantene. Alle fortalte at de anså det som viktig å gjøre det bra på ulike prøver og oppgaver de fikk på skolen. Adrian sa at han alltid gjorde så godt han kunne på prøver, og Kevin fortalte f.eks. at han ønsket å være hundre prosent sikker på at det han gjorde, ble riktig. 


\section{R. Arntzen, U. R. Andreassen, F. Karlsen og B. H. Kvifte}

Når det gjaldt den andre verdikomponenten, interesse, framkom noen forskjeller i hvilken grad informantene lot seg engasjere av de ulike tekstene. Tabell 2 viser hvilke tekster informantene husket temaet på eller kunne gjengi (deler av) innholdet fra.

Tabell 2. Tekster fra den nasjonale prøven i lesing i 9. klasse som informantene refererte til.

\begin{tabular}{|l|c|c|c|c|}
\hline Tekster & Noah & Adrian & Kevin & Sara \\
\hline Hvorfor vil noen land bytte flagg? & $\mathrm{X}$ & & & $\mathrm{X}$ \\
\hline Løpe og hoppe & & & $\mathrm{X}$ & $\mathrm{X}$ \\
\hline Avokadogåten & & $\mathrm{X}$ & & $\mathrm{X}$ \\
\hline Toalett til folket! & & & $\mathrm{X}$ & $\mathrm{X}$ \\
\hline De samiske polarhelter & $\mathrm{X}$ & & $\mathrm{X}$ & $\mathrm{X}$ \\
\hline Hopp ut av sengen! & & & & $\mathrm{X}$ \\
\hline Verden, tett og tom & & $\mathrm{X}$ & $\mathrm{X}$ & $\mathrm{X}$ \\
\hline
\end{tabular}

Adrian fortalte at han forstod alle tekstene, men at han syntes at stort sett alle var kjedelige. Han husket at det hadde vært sju tekster, og gjengav temaene for to av dem, men husket ikke hva de andre handlet om. Noah syntes det var «mye interessant», men kunne ikke gi eksempler da vi bad ham fortelle hva som var interessant. Kevin syntes teksten om en gutt som løp var spennende, men han fikk ikke lest den ordentlig fordi han måtte «kjappe seg». Han kunne gjengi hovedinnholdet i fire av tekstene. Sara husket hovedinnholdet fra samtlige tekster og kunne presentere en rekke detaljer som hadde vært mer eller mindre utfordrende for henne underveis. Hun hadde en relativt klar oppfatning av hvilken tekst som gjorde sterkest inntrykk, hvilken som var morsom, hvilken som var mindre interessant osv., og hun begrunnet ofte svarene:

Det var en tekst til om at hvis du prøver å våkne eller å gå fra sengen på en annen måte, stupe kråke ut av sengen eller noe. Det var en sånn forskning på det at man ble gladere da. Og det syntes jeg jeg hadde lyst til å prøve på en måte, da.

(Sara)

Nytteverdien for våre informanter så ut til å ligge $\mathrm{i}$ at de trodde prøven ville gi dem et inntrykk av hvordan de lå an i lesing, selv om det var forskjellige oppfatninger om hvorvidt de skulle få vite resultatene. For Sara betydde det mer at hun gjorde det bra på prøven enn at skolen gjorde det bra. Kevin vektla også den personlige nytteverdien. Han begrunnet det med at norsk er hans andrespråk: «Det er ganske viktig at jeg også skjønner om jeg kan norsken sånn som jeg burde». For Adrian var det viktigere at skolen gjorde det bra enn at han selv gjorde det bra. Det begrunnet han på følgende måte:

Nasjonale prøver gjør ikke din norskkarakter bedre eller dårligere. Man har nasjonale prøver for å sjekke hvor skolen din ligger da, så den er litt viktig for meg (...). Det er aldri noen prøver jeg ikke gidder å gjøre det bra på.

(Adrian)

Noah syntes at prøven var «litt viktig». Hvordan skolen eller de andre giorde det på prøven, «burde man ikke bry seg om», sa han. 
Når det gjaldt verdien omkostninger, var det lite som tydet på at informantene bevisst hadde unnlatt å svare på utfordrende spørsmål. Sara og Adrian svarte på alle spørsmålene. Kevin unnlot å svare på noen få spørsmål, men det var fordi han trodde det kunne ta for lang tid: «Jeg måtte bare hoppe over det, og så hadde jeg tenkt til å gjøre det etterpå, men det var ikke nok tid». Noah, som var opptatt av å følge rådet fra læreren om å ta seg god tid, rakk ikke å svare på de 11 siste spørsmålene; men dette så han ikke på som noe problem: «Hadde jeg hatt mer tid, kunne jeg ha blitt ferdig».

\section{Teststrategier}

Som det framkommer av Tabell 3, beskrev både Noah og Sara at de startet med å orientere seg i materialet, men på litt ulik måte.

Tabell 3. Elevenes primærstrategier ved gjennomføringen av nasjonal prøve i lesing.

\begin{tabular}{|l|c|c|c|c|c|}
\hline & & \multicolumn{2}{|c|}{ Tekst før oppgave } & \multicolumn{2}{c|}{ Oppgave før tekst } \\
\cline { 2 - 6 } & $\begin{array}{c}\text { Orientere seg } \mathrm{i} \\
\text { materialet }\end{array}$ & Skimme & Lese & Skanne & Lese \\
\hline Noah & $\mathrm{X}$ & & & $\mathrm{X}$ & \\
\hline Adrian & & & & $\mathrm{X}$ & \\
\hline Kevin & & & & $\mathrm{X}$ & \\
\hline Sara & $\mathrm{X}$ & & $\mathrm{X}$ & & \\
\hline
\end{tabular}

Noah startet med «å skrolle litt ned på siden for å se hva teksten handla om», før han leste oppgavene. Han beskrev at han deretter lette etter et avsnitt der han trodde å kunne finne svaret, «og så leser jeg avsnittet til den oppgaven». Slik beskrev Sara orienteringsfasen:

Først så jeg hvor lang teksten var, og så så jeg på tiden, hvor lang tid jeg hadde, og når du går helt nederst, så kommer spørsmålene opp, og da kan du trykke dem ned så de blir mindre synlige, så da leste jeg teksten.

(Sara)

Når det gjaldt primærstrategier, valgte Sara å lese teksten først, og så lese oppgavene, mens de andre tre informantenes primærstrategi var å lese oppgavene først og deretter skanne teksten. Sara skilte seg med andre ord fra de tre andre informantene. Hun leste teksten før hun leste spørsmålene, mens de tre andre begynte med å lese spørsmålene og deretter skannet teksten for å finne svarene. Adrian startet riktignok prøven med å lese hele den første teksten før han svarte på spørsmålene, men da han oppdaget at det var fire svaralternativ, endret han strategi:

Etter hvert så så jeg at jeg ikke trengte å gjøre det fordi at det var lissom fire spørsmål, så jeg leste det ene spørsmålet og så gikk jeg gjennom teksten for å lete etter svaret og så var det fire alternativer, så skulle du trykke på den som var riktig eller du mente var riktig.

(Adrian) 


\section{R. Arntzen, U. R. Andreassen, F. Karlsen og B. H. Kvifte}

Også Kevin endret strategi underveis, og for hans del var det vissheten om at han leser litt seint og at tida var begrenset, som medførte endringen. Den første teksten prøvde han å lese så fort som mulig før han begynte på spørsmålene. Men han fant ut at dette tok for lang tid, spesielt når spørsmålene var vanskelige, eller når han måtte svare med fullstendige setninger. Etter hvert valgte han å begynne med å lese oppgaven, for så å skanne teksten til han fant svaret. Dette omtalte Kevin som en «strategi». På spørsmål om hva han da lette etter, svarte han: «Jeg lette som oftest etter ord som var i spørsmålet».

Tabell 4. Elevenes sekundærstrategier ved gjennomføringen av nasjonal prøve i lesing.

\begin{tabular}{|l|c|c|c|c|c|c|}
\hline & $\begin{array}{c}\text { Lese } \\
\text { teksten }\end{array}$ & $\begin{array}{c}\text { Skanne } \\
\text { teksten }\end{array}$ & $\begin{array}{c}\text { Sml. m. andre } \\
\text { spørsmål }\end{array}$ & $\begin{array}{c}\text { Elimina- } \\
\text { sjons- metode }\end{array}$ & $\begin{array}{c}\text { Utsette vanskelige } \\
\text { spørsmål }\end{array}$ & Gjetning \\
\hline Noah & & & & & & \\
\hline Adrian & & & & & $\mathrm{X}$ & \\
\hline Kevin & $\mathrm{X}$ & & & $\mathrm{X}$ & & \\
\hline Sara & & & $\mathrm{X}$ & $\mathrm{X}$ & & \\
\hline
\end{tabular}

Sml. m. andre spørsmål = sammenlikne med andre spørsmål.

Som det framkommer av Tabell 4, kan det se ut til å være en slags todeling når det gjaldt å ta i bruk sekundærstrategier: Sara og Kevin benyttet flere ulike sekundærstrategier, mens Adrian og Noah i større grad holdt seg til primærstrategien. Noah som trodde svaret alltid var å finne i et avsnitt, prøvde å lese avsnittet «om igjen og om igjen og om igjen og tenke over det", hvis han hadde problemer med å finne svaret. Adrian «leste så godt han kunne» dersom han ikke fant svaret i teksten, og så valgte han det som hørtes mest riktig ut. På spørsmål fra intervjueren om han hadde noen andre strategier dersom han ikke fant svaret ved å lese en gang til, svarte han: "Måtte bare gjette. Ja, det var bare noe gjetting, egentlig».

Kevin fortalte om en tekst der han ikke kunne benytte primærstrategien med å lese spørsmålene først og så lete i teksten, men måtte lese hele teksten og tenke gjennom hva forfatteren hadde ment med teksten for å kunne svare. Dersom flere av svaralternativene var ganske like, fant han noen ganger svaret ved å eliminere de andre alternativene:

Det var ikke det at jeg tok en sjanse. Jeg var usikker. Var det riktig? Men når jeg tenkte på det - de tre andre svara, de er ikke riktige, så da tok jeg det andre.

(Kevin)

For å mestre tidspresset prøvde han å fokusere «på den ene tingen og glemme alt det andre, for jeg vet hvis jeg ikke gjør det, så kanskje rekker jeg det ikke hvis jeg ikke fokuserer».

Sara var den eneste som konsekvent leste teksten før hun leste spørsmålene. Ofte kunne hun da svare direkte på spørsmålene, men av og til måtte hun gå tilbake til teksten: «Jeg så på ett og ett spørsmål; noen ganger måtte jeg dobbeltsjekke». Hun fortalte at enkelte spørsmål krevde at hun måtte reflektere før hun svarte, og gav selv 
en overbevisende beskrivelse av hvordan hun resonnerte for å komme fram til riktig svar på en åpen refleksjonsoppgave:

Ja, det var en tekst om en gutt som likte å løpe og til slutt ble han utkonkurrert og sluttet og så var det siste ordet i teksten, «streken», da: «Han gikk med hodet bøyd over streken.» Så stod det [i oppgaven]: «Hva tror du streken betyr i denne sammenhengen i teksten». Siden teksten handlet om helt fra da han var liten og til han ble stor, så tror jeg det betydde døden eller noe.

(Sara)

\section{Drøfting}

I resultatdelen har vi presentert elevenes motivasjon for å delta på den nasjonale leseprøven og de strategiene de fortalte at de hadde benyttet. Ingen av informantene uttrykte negative holdninger til det å delta på prøven, og alle sa at det hadde vært viktig å gjøre det bra. De to som skåret svakest, uttrykte størst mestringsforventning, mens de to som skåret høyest, hadde vært usikre eller engstelige for hvordan det ville gå. I intervjuene uttrykte alle fire informantene at de hadde prestert godt på prøven. Vi fant derimot en forskjell mellom de på laveste og høyeste mestringsnivå når det gjaldt i hvilken grad informantene kunne gjengi innholdet i leseprøvens tekster. De sistnevnte kunne gjengi innholdet i flere av tekstene og beskrive dem mer detaljrikt. Informantene beskrev flere ulike strategier. Som primærstrategi leste tre av informantene oppgavene før teksten, mens den fjerde leste teksten først. Det varierte imidlertid i hvilken grad de beskrev å ta i bruk sekundærstrategier når de ikke nådde fram med primærstrategien. Informantene på nivå 4 og 5 beskrev et større arsenal av strategier, som de gav inntrykk av å kunne bruke fleksibelt sammenliknet med informantene på nivå 1 og 2 .

\section{Testmotivasjon}

I utgangspunktet må nasjonal prøve sies å være en lowstakestest (Knekta \& Eklöf, 2015) siden den ikke har noen karaktermessige konsekvenser for prøvedeltakerne. Våre funn sammenfaller med resultatene til Hopfenbeck og Kjærnsli (2016) ved at elevene likevel fremstod som motiverte for å gjøre sitt beste. Når det gjaldt sammenhengen mellom testmotivasjon og prestasjonsnivå, fant vi noen mønstre som vi nå vil diskutere nærmere.

\section{Mestringsforventning}

Informantene på nivå 4 og 5 uttrykte begge at de hadde vært engstelige på forhånd for at spørsmålene skulle være vanskelige eller at de ikke skulle rekke å svare på alt. Denne engstelsen kan tolkes som at det var viktig for dem å gjøre det godt på prøven. Verken Eklöf og Nyroos (2013) eller Penk og Schipolowski (2015) fant noen sammenheng mellom engstelse og prestasjon. Wigfield og Eccles (1989) fant derimot at en viss engstelse kan virke skjerpende, noe som er i overensstemmelse med våre funn. 


\section{R. Arntzen, U. R. Andreassen, F. Karlsen og B. H. Kvifte}

Samtidig fant de at testangst er noe som kjennetegner lavtpresterende (se også Birenbaum \& Gutvirtz, 1993), mens våre elever på laveste mestringsnivå ikke uttrykte noen form for engstelse eller angst. Dette kan henge sammen med at de oppfatter seg som gode lesere (jf. Solheim og Gourvennec (2017).

\section{Verdier}

Når det gjaldt viktigheten, fikk vi inntrykk av at både de høyt- og de lavtpresterende vurderte det som viktig å giøre det bra på den nasjonale leseprøven. Flere studier har funnet sammenheng mellom testresultat og oppfatning av viktighet (Zilberberg et al., 2014; Wolf \& Smith, 1995). Vi fant altså ingen slik tydelig sammenheng. Det kan skyldes at våre fire informanter hadde planer om videre utdanning og derfor anså det som viktig å gjøre det bra på alt skolerelatert arbeid. Hopfenbeck og Kjærnsli (2016) fant at det var liten sammenheng mellom de anstrengelsene gutter mente de investerte i PISA-tester og hvor viktig de syntes testene var. Selv om under halvparten av guttene anså testen som lite viktig for dem personlig, var det over $80 \%$ som sa at de gjorde så godt de kunne. Vi ser noe tilsvarende som Hopfenbeck og Kjærnsli. De to informantene (gutter) som skåret på nivå $1 \mathrm{og} 2$, anså ikke testen som viktig for dem personlig, men de fortalte likevel at de anstrengte seg for å gjøre sitt beste.

Informantene viste ulik grad av interesse for tekstene. Det som skilte informantene på nivå $1 \mathrm{og} 2$ mest fra de to på nivå $4 \mathrm{og} 5$, var at de førstnevnte i svært liten grad var i stand til å gjenfortelle hva tekstene handlet om. Dette skillet kan skyldes ulike faktorer: mangelfull leseforståelse, lite hensiktsmessige strategier eller liten interesse for innholdet i tekstene.

Vi har med utgangspunkt i Schiefele og Krapp (1996) valgt å tolke hukommelse av teksten som indikator på interesse. I en senere studie fant Schiefele og kollegaer (2012) at det er en overlapping mellom interesseverdien og leseholdningen; de som generelt finner glede $\mathrm{i}$ å lese, lar seg lettere engasjere av enkelttekster. I vår studie ser vi at de to leserne som hadde sterk interessemotivasjon, også gav inntrykk av å ha noe mer positive holdninger til lesing. En av informantene syntes i utgangspunktet teksten "om gutten som løp (...) var litt spennende», men at han ikke fikk lest den «ordentlig» siden han måtte lese raskt for å være sikker på å komme gjennom alle oppgavene. Selve prøvesituasjonen vil altså kunne virke inn på hvordan leseren engasjerer seg i teksten, og kan lett overskygge fokuset på innholdet i tekstene. Det er forståelig at elever $i$ en testsituasjon er mer opptatt av å finne svar på spørsmålene enn å engasjere seg i innholdet (jf. Cohen \& Upton, 2006).

Vi har sett at informantene på mestringsnivå 4 og 5 tilla prøven en personlig nytteverdi i høyere grad enn informantene på nivå 1 og 2 . Bare informantene på de laveste mestringsnivåene nevnte at prøven ikke betydde noe for karakterene, og dette så ut til å være begrunnelsen for at de betegnet prøven som bare litt viktig for dem personlig (jf. Zilberberg et al., 2014; Wolf \& Smith, 1995). At informantene på nivå 4 og 5 ikke nevnte noe om karakterer, tolker vi som at karakterer ikke er avgiørende 
for innsatsen de investerte. Når det gjelder nyttefaktoren, er det stilt spørsmål ved hvor hensiktsmessig det er å ha med denne komponenten ved undersøkelser av motivasjon i lowstakestester, siden prestasjonen ikke får noen konsekvenser for testtakeren (Penk \& Schipolowski, 2015). Som vi har sett, indikerer likevel vår studie en forskjell mellom de høyt- og lavtpresterende når det gjelder nytteverdiens innvirkning på motivasionen.

Man kan tenke seg at innvandrerbakgrunnen til foreldrene, indirekte, kan ha virket inn på eller har hatt betydning for informantenes motivasjon, via det såkalte utdanningsdrivet (Bakken \& Hyggen, 2018). Informantene hadde relativt klare tanker om videre utdanning, og tre av dem hadde tydeligvis også drøftet dette med foreldrene. Informantene nevner både at foreldre uttrykker ønske om at barna må bestemme seg for yrke, og at foreldre ber dem om å vurdere yrkenes inntektsmuligheter. Vi fikk imidlertid ikke inntrykk av at noen av informantene hadde vært utsatt for noen form for utdanningspress. Foreldrene til våre informanter tilhører ikke de innvandrergruppene med sterkest utdanningsdriv (Bakken \& Hyggen, 2018).

\section{Teststrategier}

De fire informantene gav inntrykk av å ha jobbet strategisk under testen (jf. Afflerbach, Pearson \& Paris, 2008), men det var forskjeller når det gialdt rekkefølge og type lesing hos informantene, samt hvor fleksibelt de benyttet strategiene. Den foretrukne rekkefølgen hos tre av informantene var å lese spørsmålene for så å kunne målrette lesningen mot å finne svaret (skanning). Dette forstår vi som en overflatestrategi (Alexander et al., 2004; Alexander, 2005; Skaftun \& Solheim, 2014), noe som ofte kan være hensiktsmessig i en testsituasjon der leseoppgaven er tydelig definert (Cohen \& Upton, 2006). Enkelte oppgavespørsmål krever imidlertid andre strategier for å kunne besvares, som f.eks. å sammenholde ulike tekstsekvenser og modaliteter og å se innholdet i sammenheng med forkunnskaper. Denne type dybdestrategier beskrev de to informantene på de høyeste mestringsnivåene at de tok i bruk ved spesielt utfordrende oppgaver. Mens informantene på de laveste mestringsnivåene bare beskrev noen få overflatestrategier, beskrev informantene på de høyeste mestringsnivåene et bredere repertoar av strategier som de tok i bruk når de ikke nådde fram med primærstrategiene. De to førstnevnte fortsatte å gjøre det samme selv om primærstrategiene ikke strakk til, mens de sistnevnte så ut til å kunne endre strategi ut fra de oppgavene de stod overfor. Dette stemmer godt overens med hva annen forskning har funnet om at sterke lesere i høyere grad tilpasser strategien til formålet med lesingen (Bråten, 2007; Roe \& Jensen, 2017; Parkinson \& Dinsmore, 2018), mens svake lesere fortsetter å giøre det samme til tross for at det ikke fører fram (Solheim \& Uppstad, 2011). Det ser altså ut til at strategibruk hos våre flerspråklige informanter følger samme mønster som majoritetsspråklige på høye og lave mestringsnivåer. Vi fant et skille når det gjaldt strategibruk mellom informanter på nivå 1-2 og 4-5 i vårt utvalg, mens Roe og Jensen (2017) fant at det tydeligste skillet i deres PISA-studie gikk mellom elevene som skåret på laveste nivå og elevene på de seks andre nivåene. Det er vanskelig å si hva forskjellen skyldes, og vi kan ikke utelukke at vi ville funnet et annet mønster med et større utvalg. 


\section{R. Arntzen, U. R. Andreassen, F. Karlsen og B. H. Kvifte}

Fauskevåg (2016) hevder at nasjonale prøver gir for liten plass til motivasjon og strategibruk i forhold til den betydning disse fenomenene har for leseprosessen. Man kan imidlertid hevde at de ulike leseaspektene krever ulike strategier, og at strategibruk dermed indirekte blir vurdert; det å «reflektere over og vurdere teksters form og innhold" vil ofte kreve mer dybdestrategier enn det å "finne informasjon", der man ofte klarer å finne svar ved hjelp av overflatestrategier.

Hvorvidt tidspresset har hatt betydning for mestringsforventning, strategier og testresultater, er vanskelig å si basert på våre data. Informantene på nivå 4 og 5 hadde forut for prøven vært bekymret for om de skulle få dårlig tid, og vi har tolket det dithen at det kan ha virket skjerpende på dem underveis, noe som i tilfelle er i overensstemmelse med Wigfield og Eccles (1989). Informanten på nivå 1 var ikke bekymret for mangel på tid, men man kan spekulere i om hans prestasjon kunne ha blitt bedre dersom han hadde opplevd et mildt tidspress (jf. Walczyk et al., 1999), slik at han kanskje hadde kommet gjennom alle oppgavene.

Utdanningsdirektoratet anbefaler skolene å forberede elevene på leseprøvene, blant annet ved at elevene blir gjort kjent med oppgavetyper, mestringsbeskrivelser, formålet med prøven og enkle lesestrategier (Utdanningsdirektoratet 2017b). I intervjuene kunne ikke informantene huske at det hadde vært noen slike forberedelser på skolen i forkant av prøven. Det eneste som kom fram var at enkelte av informantene hadde fått beskjed om å bruke god tid. Manglende forberedelser vil kunne ha innvirkning både på motivasjon og strategibruk under prøven.

\section{Avsluttende kommentarer}

I denne artikkelen har vi undersøkt hvordan fire flerspråklige elever har opplevd det å delta på nasjonal prøve i lesing. Vi har vektlagt individuelle variasjoner blant informantene som skåret på høyeste og laveste nivåer på den nasjonale leseprøven i 9. klasse. Vi har ikke noe grunnlag for å hevde at det informantene forteller om motivasjon og strategier i disse intervjuene, har sammenheng med flerspråkligheten deres, eller at det er representativt for andre elever med liknende bakgrunn. Vi ser også at informantene i liten grad skiller seg fra majoritetsspråklige elever på lave og høye mestringsnivåer når det gjelder strategibruk. Informantene kommer selv i svært liten grad inn på sin flerspråklige bakgrunn når de forteller om erfaringene med leseprøven. Kevin danner et unntak ved at han to ganger under intervjuet stiller spørsmål ved sine norskferdigheter. Det er også mulig at Adrian mistenker intervjueren for å sette spørsmålstegn ved norskferdighetene, når han på spørsmål om han forstod alle ordene, så sterkt understreker at han behersker norsk: «jeg kan norsk, jeg». Dette kan være et eksempel på den sensitiviteten som enkelte elever har mot å bli kategorisert som minoritetsspråklige eller andrespråkselever.

Informantene behersket i ulik grad å lese på førstespråket (se Tabell 1). Det er interessant å se at informanten på laveste mestringsnivå oppgav at han ikke kunne lese på førstespråket, mens informanten på høyeste nivå både kunne lese og leste jevnlig på 
førstespråket. Ingen av informantene har fått leseopplæring på førstespråket på skolen, så dette er noe eventuelt familiene har tatt seg av, gjerne foreldre og/eller søsken (Arntzen \& Karlsen, 2019). At foreldre og familie med innvandrerbakgrunn tar seg av og støtter barnas lesning på førstespråket, kan være en indikator både på ønske om å gi barna kulturell tilhørighet og at vi har å giøre med en akademisk støttende familie (jf. utdanningsdriv).

Det kan være flere begrensinger ved det forskningsdesignet vi har valgt. Eksempelvis kan det i ettertid være vanskelig for elevene å huske hvilke holdninger de hadde og hvilke arbeidsmåter de valgte i prøvesituasjonen. I særlig grad gjelder dette for de av informantene som hadde vanskeligheter med å huske innholdet $\mathrm{i}$ tekstene de hadde arbeidet med. Det kan også stilles spørsmål ved validiteten ved bruk av intervju der elever rapporterer sin egen strategibruk (Veenman, 2011) og motivasjon (Fulmer \& Frijters, 2009). Det er derfor viktig å understreke at resultatene våre først og fremst gir innsikt i hvordan elevene har opplevd den nasjonale leseprøven, hvordan de i ettertid kan beskrive motivasjonen for oppgavene og hvilke strategier de husker å ha brukt. Dette er aspekter ved deltakelse på leseprøver som det er etterlyst mer kunnskap om (Eklöf, 2010; Hopfenbeck \& Kjærnsli, 2016). Selv om utvalget er lite og resultatene ikke kan generaliseres, viser den kvalitative tilnærmingen interessante mønstre i erfaringsbeskrivelsene mellom elevene som skårer på lave mestringsnivåer og elevene som skårer på høye mestringsnivåer på den nasjonale prøven i lesing.

\section{Forfatteromtale}

Ulf Rune Andreassen er professor i spesialpedagogikk ved lærerutdanningen ved Høgskolen i Østfold, der han er fagansvarlig for masterstudiet i spesialpedagogikk. Blant hans forskningsinteresser er komponenter knyttet til leseforståelse og lesevansker, som motivasjon og strategibruk.

Ragnar Arntzen er dosent i norsk ved Høgskolen i Østfold, avdeling lærerutdanning. Hans forskningsinteresser er knyttet til fagfeltet norsk som andrespråk.

Jannicke Karlsen er førsteamanuensis ved lærerutdanningen ved Høgskolen i Østfold. Hun er logoped MNLL og har for tiden en post-doktorstilling ved Institutt for spesialpedagogikk, Universitetet i Oslo. Hennes forskningsinteresser er knyttet til språkutvikling, både hos hos barn og unge med norsk som førstespråk og andrespråk.

Bjørn Harald Kvifte er tidligere førstelektor i norsk ved Høgskolen i Østfold, avdeling lærerutdanning, og har i særlig grad jobbet med språklige/språkdidaktiske emner.

\section{Litteratur}

Afflerbach, P., Pearson, P. D. \& Paris, S. G. (2008). Clarifying differences between reading skills and reading strategies. The Reading Teacher, 61(5), 364-373. doi: 10.1598/RT.61.5.1

Alexander, P. (2005). The path to competence: A lifespan developmental perspective on reading. Fournal of Literacy Research, 37(4), 413-436. doi: 10.1207/s15548430jlr3704_1 


\section{R. Arntzen, U. R. Andreassen, F. Karlsen og B. H. Kvifte}

Alexander, P., Sperl, T. A., Buehl, M. M., Fives, H. \& Chiu, S. (2004). Modeling domain learning: Profiles for the field of special education. Fournal of Educational Psychology, 96(3), 545-557. doi: 10.1037/00220663.96.3.545

Amundsen, M. L. \& Garmannslund, P. E. (2015). Leseferdigheter og motivasjon for lesing på ungdomstrinnet. Norsk Tidsskrift for Logopedi, 61(3), 16-23.

Arntzen, R. \& Karlsen, J. (2019). Språkressurser, språkvalg og språkskifte: En studie av tospråklige barn fra fem - til tolvårsalder. NOA norsk som andrespråk, 35(1), s. 32-61.

Bakken, A. \& Hyggen, C. (2018). Trivsel og utdanningsdriv blant minoritetselever $i$ videregående. Hvordan forstå karakterforskjeller mellom elever med ulik innvandrerbakgrunn? Oslo: NOVA Rapport 1/18.

Baumert, J., \& Demmrich, A. (2001). Test motivation in the assessment of student skills: The effects of incentives on motivation and performance. European fournal of Psychology of Education, 16(3), 441-462. doi: 10.1007/ BF03173192

Birenbaum, M., \& Gutvirtz, Y. (1993). The relationship between test anxiety and seriousness of errors in algebra. Fournal of Psychoeducational Assessment, 11(1), 12-19. doi: 10.1177/073428299301100102

Bråten, I. (2007). Leseforståelse - om betydningen av forkunnskaper, forståelsesstrategier og lesemotivasjon. Viden om lesning, 2, 3-11.

Cohen, A. D. \& Upton, T. A. (2006). Strategies in responding to the new TOEFL reading tasks (Monograph no. 33). Princeton, NJ: ETS. doi: 10.1002/j.2333-8504.2006.tb02012.x

Cole, J. S., \& Osterlind, S. J. (2008). Investigating differences between low- and high-stakes test performance on a general education exam. The fournal of General Education, 57, 119-130.

De Paola, M. \& Gioia, F. (2016). Who performs better under time pressure? Results from a field experiment. Fournal of Economic Psychology, 53, 37-53. doi: 10.1016/j.joep.2015.12.002

Eklöf, H. (2010). Testmotivation och testprestation: Motivationsaspekter i internationella kunskapsmätningar. I E. Elstad \& K. Sivesind (Red.), PISA - sannheten om skolen? (s. 258-267). Oslo: Universitetsforlaget.

Eklöf, H. \& Nyroos, M. (2013). Pupil perceptions of national tests in science: perceived importance, invested effort, and test anxiety. European Fournal of Psychology of Education, 28(2), 497-510. doi: 10.1007/s10212012-0125-6

Fauskevåg, O. (2016). Nasjonale prøver i lesing - eit godt mål på leseferdigheit? Tidsskriftet FoU $i$ praksis, 10(1), 7-21.

Fulmer, S. M. \& Frijters, J. C. (2009). A review of self-report and alternative approaches in the measurement of student motivation. Educational Psychological Review, 21, 219-246. doi: 10.1007/s10648-009-9107-x

Hopfenbeck, T. N. (2010). Elevstemmer fra PISA 2006. I E. Elstad, K Sivesind (Red.) PISA- sannheten om skolen? (s. 268-280). Oslo: Universitetsforlaget.

Hopfenbeck, T. N., \& Kjærnsli, M. (2016). Students' test motivation in PISA: the case of Norway. The Curriculum fournal, 27(3), 406-422. doi: 10.1080/09585176.2016.1156004

Hvistendahl, R. \& Roe, A. (2009). Leseprestasjoner, lesevaner og holdninger til lesing blant elever fra språklige minoriteter. Norsk Pedagogisk Tidsskrift, 23(4), 250-263.

Kjærnsli, M., \& Jensen, F. (2016). PISA 2015 - gjennomføring og noen sentrale begreper. I M. Kjærnsli \& F. Jenssen (Red.) Stø kurs. Norske elevers kompetanse i naturfag, matematikk og lesing i PISA 2015 (s. 11-31). Oslo: Universitetsforlaget.

Knekta, E., \& Eklöf, H. (2015). Modeling the test-taking motivation construct through investigation of psychometric properties of an expectancy-value-based questionnaire. Fournal of Psychoeducational Assessment, 33, 662-673. doi: 10.1177/0734282914551956

Kulbrandstad, L. (2003). Lesing på andrespråket. I L. Kulbrandstad Lesing i utvikling (s. 214-234). Bergen: Fagbokforlaget.

Lewandowski, L. J., Berger, C., Lovett, B. L. \& Gordon, M. (2016). Test-taking skills of high school students with and without learning disabilities. Fournal of Educational Research, 34(6), 566-576. doi: 10.1177/ 0734282915622854

Monsen, M. \& Holm, L. (2018). Perspektiver på testing av flerspråklige barns lesing på et andrespråk. I A. K. H. Gujord \& G. T. Randen (Red.) Norsk som andrespråk - perspektiver på lcering og utvikling (s. 404-421). Oslo: Cappelen Damm Akademisk.

Montrul, S. (2013). Bilingualism and the heritage language speaker. I T. K. Bhatia \& W. C. Ritchie (Red.) The Handbook of Bilingualism and Multilingualism (s. 168-189). Oxford: Wiley-Blackwell.

Parkinson, M. M. \& Dinsmore, D. L. (2018). Multiple aspects of high school students' strategic processing on reading outcomes: The role of quantity, quality, and conjunctive strategy use. British fournal of Educational Psychology, 88, 42-62. doi: 10.1111/bjep.12176. 
Penk, C., \& Schipolowski, S. (2015). Is it all about value? Bringing back the expectancy component to the assessment of test-taking motivation. Learning and Individual Differences, 42, 27-35. doi: 10.1016/j. lindif.2015.08.002

Pintrich, P. R. \& de Groot, E. V. (1990). Motivational and self-regulated learning components of classroom academic performance. Fournal of Educational Psychology, 82, 33-40. doi: 10.1037/0022-0663.82.1.33

Roe,A.\& Jensen, R. E. (2017). Hva kjennetegner de svakeste elevenes lesekompetanse, lesevaner og strategikunnskap når de går ut av grunnskolen? Nordic fournal of Literacy Research, 3, 1-21. doi: 10.23865/njlr.v3.882

Roe, A. \& Lie, S. (2009). Nasjonale leseprøver i et didaktisk og testteoretisk perspektiv. I S. Dobson, A. B. Eggen \& K. Smith (Red.), Vurdering, prinsipper og praksis (s. 145-165). Oslo: Gyldendal Akademisk.

Roe, A., Ryen, J. A. \& Weyergang, C. (2018). God leseopplcering med nasjonale prøver. Om elevers leseutfordringer $i$ et mangfold av tekster. Oslo: Universitetsforlaget.

Roe, A. \& Vagle, W. (2010). Resultater i lesing. I M. Kjærnsli \& A. Roe (Red.), På rett spor. Norske elevers kompetanse $i$ lesing, matematikk og naturfag i PISA 2009 (s. 59-93). Oslo: Universitetsforlaget.

Samuelstuen, M. S., \& Bråten, I. (2005). Decoding, knowledge, and strategies in comprehension of expository text. Scandinavian fournal of Psychology, 46(2), 107-117. doi: 10.1111/j.1467-9450.2005.00441.x

Schiefele, U. \& Krapp, A. (1996). Topic interest and free recall of expository text. Learning and Individual Differences, 8 (2), 141-160. doi: 10.1016/S1041-6080(96)90030-8

Schiefele, U., Schaffner, E., Möller, J. \&Wigfield, A. (2012). Dimensions of reading motivation and their relation to reading behavior and competence. Reading Research Quarterly, 47, 427-463. doi: 10.1002/RRQ.030

Skaftun, A. \& Solheim, O. J. (2014). Tilpasset leseopplæring i en sammensatt tekstkultur. I A. Skaftun, J. O. Solheim \& P. H. Uppstad (Red.), Leseboka - leseopplaring $i$ alle fag på ungdomstrinnet (s. 33-54). Oslo: Cappelen Akademisk Forlag.

Solheim, O. J. \& Gourvennec, A. F. (2017). Gutte- og jentelesere i topp og bunn. En utforsking av leserprofiler. I E. Gabrielsen (Red.), Klar framgang! Leseferdighet på 4. og 5. trinn i et femtenårsperspektiv (s. 186-203). doi: 10.18261/9788215030258-2017-11

Solheim, O. J. \& Uppstad, P. H. (2011). Eye-tracking as a tool in process-oriented reading test validation. International Electronic Fournal of Elementary Education, 4(1), 153-168.

Steinkellner, A. (2017). Utdanning: Hvordan går det med innvandrere og deres barn i skolen? Innvandrere 2017. Hentet fra https://www.ssb.no/utdanning/artikler-og-publikasjoner/hvordan-gar-det-med-innvandrere-ogderes-barn-i-skolen

Tonne, I., \& Pihl, J. (2013). Andrespråkseleven, leseprøver og litteraturbasert leseopplæring. NORDAND Nordisk tidsskrift for andrespråksforskning, 2013, årg. 8 nr. 1, 93-116.

Utdanningsdirektoratet (2017a). Rammeverk for nasjonale prøver. Hentet fra https://www.udir.no/eksamen-ogprover/prover/rammeverk-for-nasjonale-prover/provenes-innhold/\#nasjonale-prover-i-lesing

Utdanningsdirektoratet (2017b). Forberede gjennomføringen av nasjonale prøver (Artikkel, sist endret 02.05.2017). Hentet fra https:/www.udir.no/eksamen-og-prover/prover/nasjonale-prover/forberede-gjennomforingen/

Veenman, M. V. J. (2011). Alternative assessment of strategy use with self-report instruments: a discussion. Metacognition and Learning, 6, 205-211. doi: 10.1007/s11409-011-9080-x

Walczyk, J. J., Kelly, K. E., Meche, S. D., \& Braud, H. (1999). Time Limitations Enhance Reading Comprehension. Contemporary Educational Psychology, 24(2), 156-165. doi: 10.1006/ceps.1998.0992

Wigfield, A., \& Eccles, J. S. (1989). Text Anxiety in Elementary and Secondary School Students. Educational Psychologist, 24(2), 159-183. doi: 10.1207/s15326985ep2402_3

Wigfield, A. \& Eccles, J. S. (1992). The development of achievement task values: A theoretical analysis. Developmental Review, 12, 265-310. doi: 10.1016/0273-2297(92)90011-P

Wigfield, A. \& Eccles, J. S. (2000). Expectancy-Value Theory of Achievement Motivation. Contemporary Educational Psychology, 25, 68-81.

Wise, S. L., \& DeMars, C. E. (2005). Low examinee effort in low-stakes assessment: Problems and potential solutions. Educational Assessment, 10, 1-17.

Wolf, L. F., \& Smith, J. K. (1995). The consequence of consequence: motivation, anxiety, and test performance. Applied Measurement in Education, 8, 227-242.

Zilberberg, A., Finney, S. J., Marsh, K. R. \& Anderson, R. D. (2014). The Role of Students' Attitudes and TestTaking Motivation on the Validity of College Institutional Accountability Tests: A Path Analytic Model. International fournal of Testing, 14(4), 360-384.

Zimmerman, B. J. (2000). Attaining self-regulation: A social cognitive perspective. I M. Boekaerts, P. Pintrich \& M. Zeidner (Red.) Self-regulasion: Theory, Research and Application (s. 13-39). Orlando, FL: Academic Press. 